\title{
Extent of Use of Information among Rural Women Entrepreneurs in Umuahia Agricultural Zone, Abia State, Nigeria
}

\author{
Onyebu CM* \\ Department of Entrepreneurial Studies, Micheal Okpara University of Agriculture, Nigeria
}

Submission: December 13, 2017; Published: February 01, 2018

"Corresponding author: Onyebu CM, Department of Entrepreneurial Studies, Micheal Okpara University of Agriculture, Nigeria, Email: chinweonyebu@gmail.com

\begin{abstract}
This study investigated the determinants of use of business information by rural women entrepreneurs in Ikwuano, Abia State. Data was collected using well-structured questionnaires administered to 180 rural women entrepreneurs using random sampling procedures. Frequency count, percentage, regression and Likert scale was used to analyze data. The results revealed that majority of the respondents were within the age range of 35-54 years of age, (81.1\%) were married with (5\%) of the respondents with no formal schooling, (59.4\%) with a household size of 6-10 people. A greater number of the women (97.7\%) were engaged in farming and (96.1\%) of the respondents sought business information through radio. Speed to these finding, it is therefore recommended that Government should equip the rural women with timely and relevant entrepreneurial information for consistent growth and development.
\end{abstract}

Keywords: Business information; Women; Entrepreneurs

\section{Introduction}

Women's entrepreneurship in developing countries has been hindered by the continued use of primitive technologies which usually affects the output from their ventures. This hindrance is due to the lack of or inability to access new dynamics in the world of technology to improve the growth of entrepreneurship. Part of the new dynamics is the emergence and growth of information and communication technology. From studies carried out on the growth of women's businesses, it has been observed that the use of ICT has been relevant to growth in subcontracting agreements in the production of garments [1]. As the developed economies outsource and subcontract their production processes, new opportunities emerge because enterprises are created [2]. Women being part of the vulnerable group in Third world countries are excluded from the global trends, especially exposure to ICT infrastructure and systems [2]. In Nigeria, women entrepreneurs are an integral part of economic growth. Their business activities are required both for wealth creation for families and the entire nation's economy [3]. Women's activities in entrepreneurship enable them to effectively combine their productive and reproductive roles because of the flexibility in hours of work which permit them to care for their children and also contribute sustainability to economic growth [3]. This has made women to be regarded as a central focus of economic development and public policy concerns [4]. As women entrepreneurship is undergoing a transformation process, the focus on Nigeria, specifically rural entrepreneurship is the focus of this work since their level of ICT usage is still left undetermined. Rural entrepreneurs need information to improve on their farm and other business enterprises which communicate into improvement of the quality and quantity of farm produce, business growth and overall quality of life for their family. Information as studies have shown is the act of acquiring knowledge. It is an important tool for a social development and advancement. The importance of information to a business development cannot be over emphasized: relevant information must be collected, selected, organized and disseminated for the purpose of achieving particular goals or objectives. The acquisition, processing and dissemination of proper information require an investment in information infrastructures, facilities and human capacity in order to undertake or provide relevant information needed to management for decision making [5].

A lot of new technologies has been introduced by the National Root Crop Research Institute on value addition technologies and Michael Okpara University of Agriculture Umudike has trained their host communities on how to manage their business enterprise of which Umuahia agricultural zone is one of them. 
But according to it was observed that the adoption rate is low partially due to poor extension services, so the study proposed that since these programs are aired regularly in the state, to what extent has these women accessed and utilize these technologies to acquire basic knowledge and skills on how to empower themselves.

Information is vital in any business due to its features in decision making and quick result in a business. Access to business information is also a major factor in the development of small scale enterprises. However, access to business information is not often given the same attention as other constraints facing small scale enterprises. The few studies on extent of use of business information by owners of small scale enterprises in rural areas reveal that there are gaps in the demand for, and supply of business information. The proprietors are limited in their capacity to access business information either through lack of knowledge or technology, low levels of education or because of the nature of business that they operate. As a result, the broad objective of the study to examine the extent of use of business information by rural women entrepreneurs in umuahia Agricultural Zone Nigeria, with the following specific objectives to

1. Ascertain the socio-economic characteristics of the respondents in the study area

2. Identify the type of business enterprise engaged by the rural women

3. Identify their source of information accessible to the rural women

4. Determine the extent of use of these information on their business enterprise.

5. Determine the factors influencing their information use

\section{Theoretical Framework}

The Entrepreneurship Cognition Theory [6] suggests that entrepreneurial ventures are driven by individuals and it is the individuals who will demand to use technological tools to develop their activities. Based on this theory, the adoption of ICT allows entrepreneurs to connect and interact with other important actors in improving businesses. Furthermore, ICT use in business is a potent domain for entrepreneurial endeavor [7]. Hence, the use of ICT by entrepreneurs has led to e-commerce innovation [8]. Since, the focus of this work is to evaluate ICT use among women entrepreneurs in Nigeria with emphasis on an urban local government, the Entrepreneurial Cognition Theory inculcates in the individual, the psychology of perceiving opportunities to explore. For instance, entrepreneurs appear to identify opportunities based on cues or signals from the environment that they filter and process through a number of mechanisms. The ICT revolution in business development can therefore be described as a product of cognitive process emanating from entrepreneurial activities.

\section{Empirical Review of Literature}

ICT adoption in business had been put under theoretical scrutiny by previous scholars who has examined their determinants with regard to cultural differences $[9,10]$. Other scholarly inquiry into the use of ICT in business focused on the difference between rich and poor countries regarding access to technologies available to their inhabitants [11]. ICT adoptions from the point of view of entrepreneurship scholars were concerned with individualistic approaches. It was argued that individual entrepreneurs are visionaries, providing the idea for business operations and it is believed that they have a better way of allocating resources [12]. Beneki [13] focused on the types of SMEs that benefitted from the adoption of ICTs in Greek SME sector. The study focused on how some SMEs reaped more benefits than others from the adoption of ICTs and which factors determined successful usage of ICTs. The results of the study revealed that strategy played a major role in the adoption and appropriate use of ICT by specific SMEs. It also concluded that prior entrepreneurial knowledge experience of ICT facilities determined the extent of ICT usage among entrepreneurs. Jani \& Omar [14] carried out a study a study on the success of Women Entrepreneurs in Southern Region in Malaysia. It was discovered that innovation through ICT has no direct effect on the success of women entrepreneurs in Malaysia. However, the study maintained that the nexus between ICT and women's entrepreneurship can be conducted in other cultures and nationalities. It is based on their conclusion that this study is carried out. Ojiako \& Wainwright [15] carried out studies on the diffusion of e-commerce technology to small scale agricbusiness in Nigeria. The empirical evidence suggests that ICTs and other related technologies are increasingly emerging in the communities of the developing economies such as Nigeria. It was discovered that rural actors engaged in agricultural industries felt that the implementation of ICTs could influence the development of new business process and the way existing processes are organized. The research motivated the South East Government in collaboration with Federal Government to give closer attention to their process of making Nigeria an ICTenabled country.

\section{Methodology}

The study area was Abia State. Abia State is made up of 3 agricultural zones, namely Aba, Umuahia and Ohafia with 17 local government areas. Multi stage sampling technique was used in the selection of the sample size. In the first stage, one agricultural zone (Umuahia) and two local government areas (LGA) from the zone was purposively selected. The second stage involved selection of 3 blocks from each LGA and 3 cells from each block, and the third stage involved selection of 10 farm families that are involved in non-farm activities as a livelihood diversification thereby bringing the sample size to 180 respondents. Data were generated using questionnaire and Focus Group Discussion (FGD) and were later analyzed with both 
descriptive statistics like frequency distribution and means and inferential statistics like multiple regression. Objective 1-3 were analyzed using descriptive statistics and for objective 4 a 4 -point Likert-type scale was used to generate the data and analyzed with mean scores. Objective 5 which is factors influencing the information use was analyzed using multiple regression and the explicit form is stated below

$$
\mathrm{Y}=\mathrm{f}(\mathrm{X} 1, \mathrm{X} 2, \mathrm{X} 3, \mathrm{X} 4, \mathrm{X} 5, \mathrm{X} 6, \mathrm{X} 7, \mathrm{X} 8+\mathrm{e})
$$

Where, $\mathrm{Y}=$ dependent variables (extent of information use (High extent 1; low 0

\section{X1 - X7 (independent variables)}

X1 = Age (measured in years)

$\mathrm{X} 2$ = Household size (number of people living in a household)

$\mathrm{X} 3=$ Martial status (dummy; married $=1$, single $=0$ )

X4 = Educational level (measured in years)

X5 = Business experience (measured in years)

X6 = Income (measured in naira)

$\mathrm{X} 7$ = Access to media (dummy; access $=1$, no access $=0$ )

$\mathrm{e}=$ error term

\section{Source: Field survey, 2016}

\section{Age}

Table 1: Socio-economic characteristics of the women.

\begin{tabular}{|c|c|c|}
\hline Variables & Frequency & Percentage \\
\hline Age & 17 & 9.4 \\
\hline $25-34$ & 64 & 35.5 \\
\hline $35-44$ & 52 & 28.8 \\
\hline $45-54$ & 36 & 20 \\
\hline $55-64$ & 11 & 6.1 \\
\hline Above 64 & Marital Status \\
\hline \multicolumn{3}{|c|}{34} \\
\hline Single & 146 & 18.8 \\
\hline Married & 55 & 81.1 \\
\hline \multicolumn{3}{|c|}{ Household } \\
\hline 01-May & 107 & 30.5 \\
\hline 06-0ct & 18 & 10 \\
\hline Above 10 & 75 & 41.6 \\
\hline \multicolumn{2}{|c|}{ Educational Status } \\
\hline No formal education & 45 & 20.5 \\
\hline Primary education & 37 & 12.7 \\
\hline Secondary education & 23 & \\
\hline Tertiary education & & \\
\hline
\end{tabular}

Table 1 shows the age category of the respondents. About nine percent of the respondents were in the age category of 2534 years, thirty-six percent were in the age category of 35-44 years, twenty-nine percent of the respondents were in the age category of 45-54 years, twenty percent of the respondents were within the age bracket of 55-64 years and six percent of respondents were above 64 years of age. From the table, above it could be seen that majority (64.3\%) of the respondents fall within the age bracket of 35-54 years. This age range is regarded as the economically productive section of the population, which implies that the women were able-bodied and could actively engage in income generating activities.

The trend may have significant implication for ICTs usage since the most elderly might be less interested in information seeking and less efficient.

\section{Marital Status}

The study also revealed that, about (81.1\%) were married and $(18.8 \%)$ were single. This implies that there were more married individuals involved in income generating activities than those that are single. This could be because of the need to support their husbands in sustaining their families (Table 2).

Table 2: Extent of use of business information in entrepreneurial activities.

\begin{tabular}{|c|c|c|c|c|c|c|}
\hline Variable & High & Moderate & Low & Total & Mean & Remark \\
\hline Marketing & 114 & 92 & 96 & 302 & 1.67 & $* * *$ \\
\hline Production & 90 & 98 & 101 & 289 & 1.6 & $* * *$ \\
\hline Technical & 45 & 88 & 121 & 254 & 1.41 & $* * *$ \\
\hline Weather & 39 & 104 & 115 & 258 & 1.43 & $* * *$ \\
\hline $\begin{array}{c}\text { Global } \\
\text { information }\end{array}$ & 27 & 64 & 139 & 230 & 1.27 & $* * *$ \\
\hline
\end{tabular}

\section{Household Size}

The results on table above shows that (30.5) of the women had a household size of between 1-5, 59.4\% had a household size of $6-10$ persons, and $10 \%$ of the women had a household size of above 10 persons. The results show that the rural women with larger families calls for greater reasonability on the household heed especially the women.

\section{Education Level}

The study also revealed that about $41.6 \%$ of the respondents had no formal education, $25 \%$ had primary education, $20.5 \%$ had secondary education and $12.7 \%$ had tertiary education. This implies that most of the respondents were literate. For the illiterate ones, their income generating activities can be limited except they are improved by learning. This has also posed significant constraints to accessing information which is beneficial and hence, affects women's ability to acquire the skills needed for more income productive activities. 
This finding show that a majority of the women entrepreneurs were not graduates and may not fully appreciate the role of information communication technologies in the improvement of their business.

\section{Source: Field survey, 2016}

**Multiple responses: The result shows that the respondents are engaged in farming business and other business enterprise. Farming (97.7\%), (96.1\%) in processing of agro products, $(87.2 \%)$ hair dressing, (86.1\%) tailoring, $(79.4 \%)$ food vendoring, (35\%) weaving of clothes and (32.7\%) mat making. According to UNCTAD (2014), women's micro enterprise and small subsistence business play a crucial role in ensuring the survival of poor household and in building up of women's confidence.

\section{Source: Field Survey 2016}

**Multiple responses: Results on Table 3 shows that majority of the rural women source business information through radio (96.1\%), television (92.7\%), phones $(90.5 \%)$, friends and relatives (80\%). It was also discovered that rural women weren't conversant with newspapers (67.2\%), magazine (51.6\%) and NGOs (32.2\%) as a result of their limited access to those sources.

Table 3: Distribution of respondents according to enterprise.

\begin{tabular}{|c|c|c|}
\hline Enterprise & Frequency & Percentage \\
\hline $\begin{array}{c}\text { Processing of agro } \\
\text { products }\end{array}$ & 173 & 96.1 \\
\hline Hair dressing & 157 & 87.2 \\
\hline Farming & 176 & 97.7 \\
\hline Food vedoring & 143 & 79.4 \\
\hline Mat making & 59 & 32.7 \\
\hline Weaving of clothes & 63 & 35 \\
\hline Tailoring & 155 & 86.1 \\
\hline
\end{tabular}

With the trend towards information and services increasingly becoming digital based in both the pubic and private sector, entrepreneurs without access to the technology have a clear disadvantage.

Source: Field data, 2016

$$
\begin{aligned}
& * * *=\text { Significant } \\
& *=\text { Not significant }
\end{aligned}
$$

Decision rule 2

2.00 and above $=$ high utilization

1.00-1.5 = moderate utilization

$0-1.00=$ low utilization

10. Results

Table 4 shows extent of use of business information on entrepreneurial activities. From the results, the respondents' had moderate use of marketing information $(\mathrm{x}=1.67)$ and production $(x=1.60)$ while low utilization was recorded for weather $(x=$ 1.43), technical $(x=1.41)$ and global information $(x=1.27)$. This limited use of information will affect their performance drastically. Looking at the information needs of rural women in Nigeria, [16] posits that rural people need information on how to apply fertilizers in the farm, preservation of harvest crops and marketing of their farm produce. The range of potential benefits ICTs offer is extensive, including better access to crucial information in areas such as business development, [17] market and pricing information, production technologies, compliance, forecast and training.

Table 4: Distribution of respondent according to sources of entrepreneurial information.

\begin{tabular}{|c|c|c|}
\hline Information Source & Frequency & Percentage \\
\hline Radio & 173 & 96.1 \\
\hline Television & 167 & 92.7 \\
\hline Newspaper & 121 & 67.2 \\
\hline Phone & 163 & 90.5 \\
\hline Friends and Relative & 144 & 80 \\
\hline Magazines & 93 & 51.6 \\
\hline NGO & 58 & 32.2 \\
\hline Fellow entre & 157 & 87.2 \\
\hline
\end{tabular}

Source: Field survey, 2016

Table 5: Factors influencing extent of use of business information of

\begin{tabular}{|c|c|c|c|}
\hline Variables & Coefficient & $\begin{array}{c}\text { Standard } \\
\text { Error }\end{array}$ & T-value \\
\hline Constant & 0.6362 & 0.275 & 2.571 \\
\hline Age & -1.2005 & 0.061 & $-4.210 * * *$ \\
\hline Household size & -0.0065 & 0.001 & $5.885^{* * *}$ \\
\hline Marital status & -0.1455 & 0.066 & $2.258^{* * *}$ \\
\hline $\begin{array}{l}\text { Educational } \\
\text { level }\end{array}$ & 7.6316 & 2.507 & $3.470^{* * *}$ \\
\hline $\begin{array}{l}\text { Years of } \\
\text { experience }\end{array}$ & 1.7892 & 1.011 & $1.866^{* * *}$ \\
\hline Income & -9.30 E.06 & $2.11 \mathrm{E}$ & 0.004 \\
\hline $\mathrm{R} 2$ & 0.772 & & \\
\hline R2 Adjusted & 0.7286 & & \\
\hline F-ratio & 17.02 & & \\
\hline
\end{tabular}
the respondents

Table 5 shows the regression analysis of factors influencing extent of use of business information by women entrepreneurs in the study area. The coefficient of multiple determination. F-value shows proportion of the variation explained by the model which gave a value of (17.02), as per the $\mathrm{R} 2$ value $=0.772$. This implies that there is exiting relationship between $\mathrm{Y}$ variables and other $\mathrm{X}$ variables, whereby $77 \%$ of the variables observed was explained by the model, while the remaining $33 \%$ was accounted by error term. Therefore, the model is fit for the study. 
The coefficient of age was negative $(-1,2005)$ and significant at $1 \%$ level of probability. This implies that as the women's age increase the extent of use of information decreases, in order words, the younger the women, the higher their information use. The result is in line with [18] who reported that farmers at younger age have higher information seeking information behaviour. Household size was found to have a negative coefficient $(-0.0065)$ and significant at $1 \%$ level of probability. This implies that increase in household size leads to a reduction in the use of information by the respondents. Educational level had a positive coefficient (7.6316) which significantly influenced the extent of information use of the respondents.

The coefficient of years of business experience (1.7892) was positive and significantly related to extent of information use at $1 \%$ level. This implies that the extent of use of business information increases with years of business experience.

\section{Conclusion}

The study investigated extent of use business information use by the respondents in the study. Major findings revealed that all the variables age, household size, [19] income, business experience, marital status, educational level and access to media had moderate and low utilization. Based on these findings the study recommends that extension agents that are regularly in contact with these women should endeavor to package entrepreneurial skills need for effective business operation along with normal job specification.

\section{References}

1. Tonetti BR (2001) ICT for Women Entrepreneurship in Asia-Pacific. Expert Group Meeting on ICT policy from a Gender Perspective, 2001, December $18^{\text {th }}-19^{\text {th }}$, Asian Pacific Centre for Transfer of Technology (APCTT).

2. Oyelaran-Oyeyinka B (2007) ICTs and Industrial Development: Transformation and Employment Generation. African economic Research Consortium (AERC), Netherlands, pp. 4-31.

3. Soetan F (1997) Entrepreneurship and Nigerian Women-Is there any meeting point? Journal of Small Enterprise Development 8: 312-315.

4. Bagby RD (2004) Enhancing Succession Research in the Family Firm: A Commentary on Toward an Integrative Model of Effective FOB Succession. Entrepreneurship Theory and Practice 28(4): 329-333.
5. Bida MA, CLN, Abba T, CLN (2014) Utilization of information among small scale entrepreneurs (SSEs) in Niger State, Nigeria. Inter J Acad Lib Info Sci 2(7): 66-72.

6. Baron RA (2004) The Cognitive Perspective: A Valuable Tool for Answering Entrepreneurship's Basic 'Why' Questions. Journal of Business Venturing 19(5): 221-240.

7. Amit R, Zott C (2001) Value Creation in E-Business. Strategic Management Journal 22(6-7): 493-520.

8. Martinez CA, Williams C (2010) National Institutions, Entrepreneurship and Global ICT Adoption: A Cross-Country Test of Competing Theories. Journal of Electronic Commerce Research 11(1): 73-91.

9. Erumban AA, SB De Jong (2006) Cross Country Differences in ICT adoption: A Consequence of Culture? Journal of World Business 41(4): 302-350.

10. Zhao H, kim S, Suh T, Du J (2008) Social Institutional Explanation of Global Internet Diffusion: A Cross Country Analysis. Selected Reading on Global Information Technology, New York, USA, p. 28

11. Goldstein A, O'Connor D (2002) E-commerce for Development: Prospects and Policy Issues.

12. Casson MC (1997) Information and Organization: A New Perspective on the Theory of the Firm. Oxford University press, UK.

13. Papastathopoulos A, Beneki C (2010) Does Entrepreneurial Experience and Strategy Really Matter for ICT Performance? A Greek Cross-Border Empirical Study. The Electronic Journal Information System Evaluation 13(2): 177-186.

14. Alam SS, Jani MM, Omar NA (2011) An Empirical Study of Success Factors of Women Entrepreneurs in Southern Region in Malaysia. International Journal of Economics and Finance 3(2): 1-10.

15. Aleke, Ojiako, Wainwright (2011) ICT Adoption in Developing Countries: Perspectives from Small-Scale Agribusiness. Journal of Enterprise Information Management 24(1): 68-84.

16. Unomah (1998) Rural Librarianship: Panacea for Grassroots Development. A paper presented at Annual General Conference of the Nigeria Library Association. Delta State Chapter. Held at College of Education (technical), Asaba, Nigeria.

17. Okunade EO (2005) Influence of Leadership Role on Women Activities in Women based Rural Development Projects in Osun State. Research Journal of Social Sciences 2(5): 14-22.

18. Onuekwusi GC, Odoemelam LE, Kanu RI (2017) Capacity building on cocoyam value addition training for rural women in Abia state, Nigeria. Agricultural Research and Technology Open Access Journal 6(4): 1-5.

19. United Nations Conference on Trade and Development (2014) Empowering Women Entrepreneurs through information and communication technology. A practical guide vol.9, New York, USA.

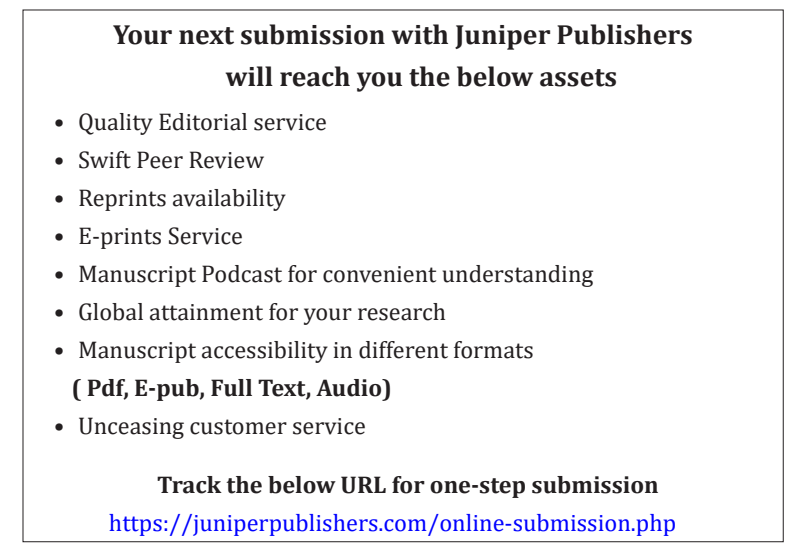

\section{Your next submission with Juniper Publishers} will reach you the below assets 